\title{
ANALYSIS OF EDUCATION SYSTEM COMPARISON IN INDONESIA AND THE NETHERLANDS
}

\author{
Syafni Gustina Sari ${ }^{1}$, Rieke Alyusfitri $^{2}$, Rusdinal $^{3}$, Azwar Ananda $^{4}$, Nurhizrah Gistituati $^{5}$ \\ 1'syafnigustinasari@bunghatta.ac.id, ${ }^{2}$ alyusfitririeke@gmail.com,, ${ }^{3}$ rusdinal@ fip.unp.ac.id \\ , ${ }^{4}$ ananda.azwar4127@gmail.com, ${ }^{5}$ gistituatinurhizrah@gmail.com \\ nal@fip.unp.ac.id, \\ 1,2,3,4,5 Universitas Negeri Padang , Jl. Prof.Dr. Hamka,Air Tawar Barat, Padang
}

\begin{abstract}
Education is an effort to foster and shape human personality so that it is in accordance with the values contained in community life. Education is also an important pillar for the development and progress of a nation, a developed nation is a nation that has a good quality of education because the progress of the nation is very much dependent on the quality and education system of a nation. The Indonesian and Dutch education systems have significant differences. The Netherlands implements a majoring education system that has been started when students graduate from basic education, while the education system in Indonesia does not use the majors method after students graduate from basic education but students can choose majors after they finish senior secondary education or when they want to enter higher education
\end{abstract}

Keywords : Education, Indonesia, the Netherlands

\section{Peliminary}

Education is an effort to foster and shape human personality so that it is in accordance with the values contained in community life. Education is also an important pillar for the development and progress of a nation, a developed nation is a nation that has a good quality of education because the progress of the nation is very much dependent on the quality and education system of a nation. According to Novalita, (2017: 2) Education is one of the main keys to the progress of a nation which will form good quality human resources in terms of spiritual, intelligence and skills.

Indonesia at this time is no longer faced with armed threats but the Indonesian nation is faced with ideological destruction caused by the abuse of increasingly rapid technological advances. This requires the Indonesian people to create human resources who are able to compete with developed countries in order to advance education in Indonesia in the future. Education in Indonesia must be continuously improved and developed so that Indonesia will become a developed country and not be left behind with other countries in Europe.

Comparison according to KBBI can be interpreted as comparison. Comparative studies can also be interpreted as studies and observations that aim to find solutions to problems with usal relationships that are in accordance with the conditions and situations being studied or compared. Through comparative analysis we can find out how the strategies of other countries in improving the education system and increasing human resources, the comparison also provides the latest recommendations and innovations in policy making in order 
to build and advance the education system in Indonesia.

Indonesia as one of the countries that was colonized by the Dutch state also received influence in the education sector from the Netherlands. This can be proven by the same learning strategies as the Netherlands, one of which is in the level of primary school education. The Netherlands has a better quality education system than the existing education system in Indonesia. This is suitable and very interesting to conduct a comparative analysis of Indonesian education with the Netherlands.

\section{Result and Discussions}

\subsection{The education system in Indonesia}

Indonesia adheres to a national education system. The national education system has described in detail and systematically the education system in Indonesia as stated in Law no. 20 of 2003. In addition, it is also contained in the 1945 Constitution in the fourth paragraph which explains that Indonesian education must be able to provide the best service for the nation's next generation in order to educate the nation's life. This explains that the national education policy system is evident in shaping the learning capacity and ability of the nation to innovate optimally.

According to Law no. 20 of 2003 concerning the National Education System in chapter VI article 16 explains that the path, level and type of education can be realized in the form of an education unit implemented by the government, local government and the community. The formal education network in Indonesia is divided into 3 levels of education, namely: basic education, secondary education and higher education. These schools are managed by three ministries. Primary and Secondary Education are in the Ministry of Primary and Secondary Education and Culture. Meanwhile, Higher Education is in the Ministry of Research, Technology and Higher Education. There are also primary, secondary and tertiary education, which are religion-based and managed by the Ministry of Religion. It is clear that this national education system aims to provide academic knowledge, increase creativity and foster character in accordance with the 1945 Constitution.

Education in Indonesia requires a 12 year study program that has been issued by a presidential regulation (perpes) starting from the age of approximately 7 years. Education starts in the first 6 years of primary education, the next 3 years of junior secondary education and the last 3 years of carrying out senior secondary education. After 12 years of education students can choose to continue their education to university or directly enter the world of work

The current Indonesian education system is a form of the mandate of the 1945 Constitution and Law no. 20 of 2003 in which national educational institutions are very enthusiastic in conducting international education competitions. The grouping of students who have the potential and intelligence that is in accordance with the abilities of these students is one of the implied evidence in the future development of education.

In its management, the National Education System is held in a centralized manner, where educational objectives, learning materials and methods, education personnel and promotion requirements are regulated by the central government and apply to the national level (Munirah, 2015). Although it is said that the community plays a role as a partner of the government in providing education, in practice it is still determined by the government.

\subsection{The education system in the Netherlands}

The education system in the Netherlands is different from the education system implemented in Indonesia. The Indonesian education system implements a 12 -year compulsory education system which is 
divided into 3 parts including: basic education, junior secondary education and senior secondary education, while education carried out by the Dutch state does not necessarily have to take this education path. According to Maksum, (2016: 133) the education system in the Netherlands has levels of education, including primary education, junior secondary and vocational education, and general senior secondary, vocational colleges and universities.

Education in the Netherlands after graduating from elementry school or basic education they take a kind of exam. From the results of the exam, it is divided into 3 levels, namely VMBO, HAVO and WO. The education system in the Netherlands can also be seen in majors starting at the primary level by taking into account students' interests and academic abilities. Primary and secondary education. Primary level education in the Netherlands lasts for approximately 8 years ( 7 of which are compulsory education), from the time a child is 5 years old. In the last year of primary education, students take an exam to determine their further education (lasts from 12-16 years of age) which is determined by the results of their test scores to determine the academic level they will get.

Student examination results determine the advanced academic level that will be taken next. Students who have low academic scores will be directed to join the VMBO program (4 years) which is a combination of general education and majors, after graduating from VMBO they can continue to MBO education and can work immediately. Students with intermediate academic abilities can take HAVO (5 years) after which they can join HBO (equivalent to universities in Indonesia but use applied science more). Meanwhile, students who have the highest academic scores are entitled to participate in WO (6 years) and then apply to universities such as the education system in Indonesia.

To enter the HBO (hogeschool / university of professional education) every prospective student is required to have a HAVO diploma, while to enter WO, each prospective student is required to have a VWO diploma. Due to limited space, some WO programs use a lottery system in the admission process. Meanwhile, potential students who are over 21 years of age may enter tertiary education in the Netherlands after successfully passing the entrance tests from the following educational bodies.

Since 2002 the education system in the Netherlands has used the ECTS (European Credit Transfer System) credit / point system which is applicable in almost all of Europe. One credit represents 28 hours of work / study on campus (excluding home study hours) and 60 credits represents 1 full academic year. Meanwhile, the scoring system has absolutely no change from the previous system, namely from a scale of 1 (low sting) to a scale of 10 (very satisfying) with the lowest pass score of 6 . Generally, a value of 9 is very rarely given, a value of 10 is considered very strange if it is obtained, and ratings 1-3 are used very rarely

\subsection{Educational curriculum in Indonesia and the Netherlands}

The curriculum is a collection of subjects and educational programs provided by educational institutions that contain learning designs for a period of education level. According to Bahri, (2017: 18) the curriculum is all facilities, programs and activities of educational institutions in order to realize the vision and mission of an institution. Therefore the curriculum can be interpreted as a set of structured and planned learning programs in order to realize educational goals that are in accordance with the vision and mission of an institution.

The school curriculum includes several subjects that will be taught at the school. According to Maksum (2016: 136) the curriculum applied in the Netherlands was developed by a body called The Dutch Institute for Curriculum Development or SLO, the curriculum developed by SLO contains several subjects including: Language, Mathematics, Science (Science). Nature), Physical Education, ICT (Information and Communication Technology) and others. If brought to Indonedia SLO is the same as the Curriculum Development Center under the authority of the Ministry of National Education. 
The curriculum applied in the Netherlands is different from the curriculum applied in Indonesia, the Dutch education curriculum has been recognized internationally as evidenced by the highly valued Dutch university diploma in the international world. Programs implemented in the Netherlands must be registered and accredited to NVAO to be recognized as a trusted program. The most prominent thing about the Dutch education system is the majors program that has been started since elementary school. Meanwhile, the curriculum in Indonesia does not use a majors system after primary school, but in Indonesia it does a majors system after senior secondary education.

The curriculum in Indonesia has developed from time to time in accordance with the conditions and progress of the times, the curriculum continues to develop and be revised with the aim of perfecting the education system applied in Indonesia. The curriculum changes that are designed must be in accordance with and not in conflict with Pancasila and the 1945 Constitution. In accordance with the development of the curriculum era in Indonesia, it is divided into 2 periods, namely the period before independence and the period after independence (Wahyuni, 2015: 232).

The pre-independence curriculum began in the colonial period, the curriculum at this time had the aim of spreading religion and making trading easier in Indonesia. Then the period after independence, the curriculum in Indonesia underwent several stages of change including:

\section{a. Curriculum 1947}

The first curriculum after independence was named "the 1947 lesson plan", this curriculum is more concerned with character education, state and community awareness. The learning methods at that time were more concerned with the way the teacher taught and the way students learned learning

b. Curriculum 1952

The curriculum in Indonesia in 1952 was given the name "1952 unraveled lesson plan" which was a refinement of the previous curriculum. The characteristic of the 1952 curriculum is learning that connects learning with everyday life. Subjects in this curriculum are grouped into several groups, namely skills, intelligence, physical, moral and emotional.

c. Curriculum 1964

The 1964 curriculum was a curriculum to improve the education system from the 1952 curriculum which was named "the 1964 education plan". The characteristics of this curriculum are learning aimed at the Pancawardhana program which includes the development of creativity, work, initiative, morals and feelings.

d. Curriculum 1968

The 1968 curriculum underwent a change from the Pancawardhana program to basic knowledge, special skills and development of the spirit of Pancasila. The aim of the 1968 curriculum was to form humans who have a true Pancasila spirit.

e. Curriculum 1975

The 1975 curriculum was aimed at making education more efficient and more effective and providing more detailed lessons. This curriculum has received a lot of criticism from several circles of society because of the teacher's too many duties.

f. 1984 curriculum

The 1984 curriculum students become learning subjects that students are expected to observe, classify, discuss and report on. This curriculum uses the CBSA method (active student learning method.

g. Curriculum 1994

The 1994 curriculum had a change in the time division system from semesters to quarterly which was expected that students could understand the learning material. The learning objectives in this curriculum place more emphasis on understanding and problem solving skills

h. Curriculum $2004(\mathrm{KBK})$

The 2004 curriculum is better known as the competency-based curriculum (KBK), which is a 
combination of skills, knowledge, character and habits in thinking and acting. This method is considered less competent because the student's competency measurement tool still uses a multiple choice format.

i. Curriculum 2006 (KTSP)

The education unit level curriculum (KTSP) or the 2006 curriculum is a curriculum of refinement of the actual curriculum, seen from the point of view of the content and the process of its achievement. Teachers are given more freedom in designing learning methods according to the conditions and circumstances of students at school

j. Curriculum 2013

The 2013 curriculum emphasizes character education, skills, and student creativity. Students are expected to be able to observe, reason, ask questions, discuss and be able to communicate the learning results that have been learned, in this curriculum students are also required to be active students and have a critical way of thinking.

These changes are a logical consequence of changes in the political, socio-cultural, economic and science and technology systems in the nation and state society. This is because the curriculum as a set of educational plans needs to be developed dynamically in accordance with the demands and changes that occur in society

\section{Conclusion}

From the comparative analysis of Indonesian and Dutch education, it can be concluded that the Indonesian and Dutch education systems have significant differences. The Netherlands implements a majoring education system that has been started when students graduate from primary education, while the education system in Indonesia does not use the majors method after students graduate from basic education but students can choose majors after they have completed senior secondary education or when they want to enter college. The Netherlands also does not overload students with many tasks.

Based on the conclusions that have been formulated, the suggestion is that the government should make policies that have been proven to have been successful in improving the quality and quality of human resources in the country. Indonesia must also be able to become a developed country that is able to compete with other countries.

\section{References}

Alhamuddin.2014. SEJARAH KURIKULUM DI INDONESIA (Studi Analisis Kebijakan Pengembangan Kurikulum). Nur El-Islam, Volume 1, Nomor 2, Oktober 2014

Bahri, S. (2017). Pengembangan Kurikulum Dasar dan Tujuannya. Jurnal Ilmiah Islam Futura, 11(1), 15-34.

Novalita, Rahmi. 2017. Perbandingan Pendidikan Negara Belgia Dengan Negara Indonesia. Jurnal Spasial, Volume 4, Nomor 3, 2017 : 1 12. Padang. Program Studi Pendidikan Geografi STKIP PGRI Sumatera Barat.

UU RI NO. 20 Tahun 2003 Tentang Sistem Pendidikan Nasional. (2003). Jakarta: Kreasi.

Maksum, H. (2016). Perbandingan Pendidikan Jasmani di Indonesia dan Belanda. Jurnal Pendidikan Olah Raga, 3(2), 131-145.

Munirah. (2015). SISTEM PENDIDIKAN DI INDONESIA: antara keinginan dan realita. Sistem Pendidikan Di Indonesia, 02(36), 233245.

Wahyuni, F. (2015). Kurikulum dari masa ke masa. Jurnal, Al-Adabiya, 10(2). 